Bond University

Research Repository

\title{
Evidence for Rehabilitation Interventions After Acute Lateral Ankle Sprains in Athletes: A Scoping Review
}

Tee, Eugene; Melbourne, Jack; Sattler, Larissa; Hing, Wayne

Published in:

Journal of Sport Rehabilitation

DOI:

10.1123/jsr.2021-0244

Licence:

Other

Link to output in Bond University research repository.

Recommended citation(APA):

Tee, E., Melbourne, J., Sattler, L., \& Hing, W. (2022). Evidence for Rehabilitation Interventions After Acute Lateral Ankle Sprains in Athletes: A Scoping Review. Journal of Sport Rehabilitation, 31(4), 457-464. https://doi.org/10.1123/jsr.2021-0244

\section{General rights}

Copyright and moral rights for the publications made accessible in the public portal are retained by the authors and/or other copyright owners and it is a condition of accessing publications that users recognise and abide by the legal requirements associated with these rights.

For more information, or if you believe that this document breaches copyright, please contact the Bond University research repository coordinator 


\section{Title:}

2 Evidence for rehabilitation interventions after acute lateral ankle sprains in athletes: A scoping

3 review

4

5 Running title:

6 Rehabilitation after acute lateral ankle sprain

7 Authors

8 Eugene Tee $^{1}(\mathrm{DPT})$, Jack Melbourne ${ }^{1}(\mathrm{DPT})$, Larissa Sattler ${ }^{1}(\mathrm{PhD})$, Wayne Hing ${ }^{1}(\mathrm{PhD})$

\section{Institutions:}

${ }^{1}$ Bond University Institute of Health and Sport, 2 Promethean way, Robina, QLD, Australia 4226

13 Author details:

14 Eugene Tee (Corresponding Author)

15 Position: Physiotherapist

16 Institution: Bond Institute of Health and Sport, Bond University

17 Postal address: 6/30 Crump Street, Holland Park West, 4121, QLD, Australia

18 Email: eugenetee93@gmail.com

Jack Melbourne

21 Position: Physiotherapist

22 Institution: Bond Institute of Health and Sport, Bond University

Email: jack.melbourne12@outlook.com

Dr Larissa Sattler

Assistant Professor - Doctor of Physiotherapy program, Bond University

Dr Wayne Hing

30 Professor - Doctor of Physiotherapy program, Bond University

31 Email: whing@bond.edu.au

32

All authors (ET, JM, LS, WH) certify that he or she has no commercial associations (e.g., consultancies, stock ownership, equity interest, patent/licensing arrangements, etc.) that might pose a conflict of interest in connection with the submitted article.

36 
37 Title: Evidence for rehabilitation interventions after acute lateral ankle sprains in athletes: A scoping review

\section{ABSTRACT}

Context: Acute lateral ankle sprain (LAS) is a common injury in athletes and is often associated with decreased athletic performance, and if treated poorly, chronic ankle issues such as instability. The physical performance demands such as cutting, hopping and landing involved with certain sport participation suggests that the rehabilitation needs of an athlete after LAS may differ from the those of the general population.

Objective: To review the literature to determine the most effective rehabilitation interventions reported for athletes returning to sport after acute LAS.

\section{Evidence Acquisition:}

48 Data Sources: Databases Pubmed, Embase, Cinahl, SportDiscus and PEDro were searched to 49 July 2020.

Study Selection: A scoping review protocol was developed and followed in accordance with the

51 PRISMA-ScR guidelines and prospectively registered (https://osf.io/bgek3/). Study selection

52 included published articles on rehabilitation for ankle sprain in an athletic population. investigated, outcome measures, measurement tool and follow up period. analysis of randomized controlled trials (RCT) and critical methodological appraisal was also conducted. 
58 Evidence Synthesis: 37 articles were included in this review consisting of 5 systematic and 20

59 narrative reviews, 7 RCTs, a single case series, case report, position statement, critically

60 appraised topic, and descriptive study were also included. RCT interventions included early

61 dynamic training, electrotherapy, and hydrotherapy.

62 Conclusions: Early dynamic training, after acute LAS in athletes, results in a shorter time to

63 return to sport, increased functional performance, and decreased self-reported re-injury. The

64 results of this scoping review support an early functional and dynamic rehabilitation approach

65 when compared to passive interventions for athletes returning to sport after LAS. Despite

66 existing research on rehabilitation of LAS in the general population, a lack of evidence exists

67 related to athletes seeking to return to sport.

68

69

70

71 Keywords: foot, rehabilitation, physiotherapy, physical therapy, return to sport.

72

73

74

75

76

77 
Introduction

Lateral ligament injuries to the ankle are a common musculoskeletal complaint, with an

81 estimated rate of one ankle injury per 10,000 people per day ${ }^{1-3}$. In a sporting population, the

82 incidence is even greater, constituting $15 \%$ to $45 \%$ of all sport related injuries ${ }^{3}$. When an

83 athlete sustains a lateral ankle sprain (LAS) this can often result in lost playing time, decreased

84 athletic performance, and if treated poorly, chronic ankle issues such as instability 4 .

85 Additionally, LAS presents a significant economic burden when medical costs and leave from work are taken into consideration ${ }^{5}$. The high frequency of LAS in athletes, alongside the costs

87 of injury management, demonstrate the importance for rehabilitation interventions to be evidence-based.

Research to date, supports non-operative management for excellent long-term outcomes when compared with surgical intervention in cases not involving a complete ligament rupture ${ }^{6-9}$. The increased costs, intra and post-operative complication risks and prolonged absence that are associated with surgical interventions are also reasons that make conservative management more favorable ${ }^{9-11}$. Clinical practice guidelines have been developed with respect to rehabilitation after LAS, however, these do not appear to inform the efficacy of rehabilitation

96 interventions specific to athletes wishing to return to sport (RTS) ${ }^{10,12}$. 
98 Considering the greater physical requirements such as cutting, jumping, hopping and landing

99

100

101

102

103

104

105

106

107

108

109

110

111

112

113 114 developed through the methodological procedure proposed by Arksey and O'Malley ${ }^{13}$ and
115 Johanna Briggs Institute ${ }^{15}$, and followed a 3-step approach:

\section{Materials and Methods}

Study design

A scoping review study design was utilised to identify key concepts, knowledge gaps and types

of evidence currently available and the protocol was prospectively registered with Open

Science Framework (https://osf.io/bgek3/) ${ }^{13}$.

\section{Data Sources and Searches}

Two researchers (ET \& JM) conducted the literature search to identify, screen and select studies

to be included in accordance with the Preferred Reporting Items for Systematic Reviews and Meta-Analysis Extension for Scoping Reviews (PRISMA-ScR) ${ }^{14}$. The search strategy was 
1. A pilot search of the database PubMed using the subject headings: (acute) AND (ankle) AND 'sprain OR injury' AND 'treat* OR manage* OR rehab* OR therap*' AND 'sport* OR athlet* OR 'funct* OR exercis*'.

2. Identified key words and terms relating to acute lateral ankle sprains and rehabilitation interventions and return to sport.

3. Execution of the final search strategy and further searching of referenced lists of the selected articles, including systematic and narrative reviews.

A search was formulated and conducted in five databases (Pubmed, Embase, Cinahl, SportDiscus and PEDro) from inception to 27 July 2020. Articles were downloaded to the EndNote reference management software (http://www.endnote.com/) for selection by ET \& JM according to the PRISMA-ScR statement ${ }^{14}$.

\section{Study Selection}

The eligibility criteria were defined by the population (athletes clinically diagnosed with acute lateral ankle sprain), concept (any study reporting on the effects of rehabilitation interventions for acute lateral ankle sprain) and context (all periods of time, outcomes, comparators, follow up, return to sport setting and during and type of intervention). The following types of publications were eligible for inclusion: intervention studies, narrative reviews, scoping reviews, systematic reviews, meta-analysis, case series and clinical commentaries. Exclusion criteria were (1) non-English language, (2) non athlete only population, (3) studies involving animals, (4) chronic ankle instability population, (5) fractures and/or dislocations, (6) deltoid ligament, 
137 peroneal, syndesmosis injuries, (7) preventative interventions, (8) surgical interventions, and (9)

138 pharmacological interventions. The following were also excluded from our review: conference 139 abstracts/proceedings, magazines and newspaper articles, grey literature and in those articles 140 where the full text was not available.

\section{Data Extraction and Quality Assessment}

Data extraction, categorization and mapping was performed by ET \& JM using methodology

144 adapted from the Joanna Briggs Institute (JBI) guidelines for scoping reviews ${ }^{15}$. The data were

145 extracted into the following categories: (1) author, (2) year, (3) aim/purpose, (4) study population (including demographic details) and size, (5) study design, (6) intervention (type,

147 comparator, duration and details), (7) outcomes, and (8) key findings.

A qualitative synthesis for all articles was undertaken, and a further quantitative synthesis of randomized controlled trials (RCT) and methodological quality appraisal was included. For

152 critical appraisal two reviewers (ET \& JM) independently scored studies using the PEDro scale, 153 where disagreement existed a consensus decision was made through discussion. The Kappa 154 coefficient statistic was used to measure the interrater reliability and agreement between the 155 two reviewers ${ }^{16}$. The PEDro scale is a methodological measure of quality used to appraise RCTs, 156 consisting of an 11-item checklist with a maximum possible score of $10^{17}$. Studies of good 
157 quality received a score of greater than 6 , fair quality scores were between 4 and 6 , and poor 158 studies received scores of less than 4 18,19.

\section{Results}

161 The search strategy yielded a total 2600 articles, of which 2525 records were removed as

162 duplicates or not meeting the pre-defined inclusion criteria. Upon completion of the title and 163 abstract screening, 75 articles were retrieved and assessed for eligibility. Subsequently, 38 full 164 text articles fulfilled the eligibility criteria and were included (Figure 1).

The number of published studies relating to rehabilitation interventions following LAS to RTS

167 has been consistent over the last 20 years. Of the 37 articles included in this scoping review, 25

168 were review articles, comprised of 20 narrative reviews and 5 systematic reviews. Also

169 included were a critically appraised topic, position statement and a descriptive study were also

170 identified (Supplementary Figure 1). The five systematic reviews investigated a range of

171 interventions including bracing, functional treatment, cryotherapy, manual mobilisation and

172 exercise ${ }^{20}$. There were also 7 RCTs included, along with a case series, and a case report.

174 Characteristics of the included reviews

175 There were five systematic reviews reported in this review containing 82 original studies (Table

176 1). The methodological quality of the included articles within the systematic reviews were 
177 classified as poor or limited quality. Additionally, methodological quality was not reported in all

178 of the included reviews ${ }^{21}$. The five systematic reviews contained literature from 1990-2012 and

179 there were several outcomes investigated for the rehabilitation of LAS. Two of the reviews

180 investigated early dynamic training ${ }^{9,22}$. The remaining three articles explored bracing vs

181 functional treatment ${ }^{21}$, cryotherapy ${ }^{23}$ and exercise and manual therapy ${ }^{24}$. A critically appraised

182 topic was included containing 3 studies exploring deep oscillation therapy in athletes with acute

183 LAS ${ }^{25}$. A position statement from 2012 proposing an evidence-based clinical guideline to treat

184 LAS was also included in this review ${ }^{10}$. This position statement explored the use of early

185 dynamic training, ice and compression, immobilization, electrotherapy and manual

186

mobilizations. Additionally, a descriptive study relating to the clinical application of cryotherapy

187

was also included in this review. The modalities of cryotherapy surveyed included an ice pack,

ice pack and cryokinetics, ice immersion, and ice immersion and cryokinetics ${ }^{26}$.

\section{Characteristics of the included intervention studies}

191 Participants

192 There was a total of 830 participants across the 7 RCTs and the overall sex ratio was $57 \%$

193 male and 43\% female. All RCTs contained both male and female participants apart from one

$194 \quad 27$ which included 22 female participants only and the average mean age was 27 years. Two

195 studies involved professional athletes (29\%), with the remainder of participants in the five

196 studies (71\%) recreationally or competitively active. The type of sport was unspecified in five

197 studies (62.5\%). The remainder included the following sports: soccer, football, basketball,

198 mixed martial arts, volleyball, handball and running. Table 2 provides a summary of 
participant characteristics across each intervention study including population, type of sport, sample size, age (mean) and gender. The case series contained 3 intercollegiate athletes comprised of 2 males aged 18 and 21 and single female aged 18 . The sports of the participants were women's lacrosse and men's basketball and soccer ${ }^{28}$. The case report examined a 29-year-old male Caucasian professional football athlete ${ }^{29}$.

\section{Intervention type and effectiveness}

The most investigated intervention in the RCTs was early dynamic training (5 studies) ${ }^{30-34}$, while one study examined the electro modality, non-invasive interactive neurostimulation ${ }^{35}$, and one study aquatic therapy ${ }^{27}$. Early dynamic training included a combination of early weightbearing, range of motion (ROM) exercises, proprioceptive or balance training, running and plyometrics, resistance strength training, or functional rehabilitation. Hydrotherapy showed more effective improvements in pain than standard land-based therapy ${ }^{27}$. Noninvasive interactive neurostimulation was effective in improving short-term outcomes, however showed no significant difference in long-term outcomes to RTS ${ }^{35}$.

Early dynamic training was effective in increasing functional performance, strength, postural control, decreasing recess fluid, and a shortened time to RTS ${ }^{30-34}$. All reported key findings and intervention details can be found in Tables 3 and 4, respectively. The case series explored the use of the Mulligan Concept Mobilization with Movement and all three participants from this study showed an increase in pain-free function at the one month follow up ${ }^{28}$. The application of acute hydrotherapy with super saturated hydrogen-rich water for acute LAS was supported 
221 in the case report. This study indicated multi session hydrotherapy within the first 24 hours may

222 provide benefits in terms of pain, swelling reduction, and ROM ${ }^{29}$.

Outcome Measures

Although a range of outcome measures were utilized across the included RCTs (Table 4), the most common were those related to pain and swelling. The visual analogue scale (VAS) was

227 frequently used to assess pain while the measurement tool to assess swelling was inconsistent across the studies. Only two RCT's listed time until RTS as an outcome measure ${ }^{30,34}$. The follow up time for an outcome measure varied between studies with the shortest being three days and longest 18 months ${ }^{34,36}$. Not all studies included a follow up assessment ${ }^{27,30,32}$. The case series utilized outcome measures examining pain, functional limitations, balance, and self-

232 reported ability to weight bear ${ }^{28}$. The case report focused on outcome measures relating to pain, swelling and weight bearing during lunge ${ }^{29}$.

236 The methodological quality of the seven RCT's was assessed using the PEDro scale

237 (Supplementary Table 1). The methodological quality in the included articles varied, ranging

238 from 3 to 8 points out of a possible 10 (Table 3). The mean PEDro score was 5.42, meaning

239 overall, the studies are classified as fair quality. One study ${ }^{31}$ demonstrated poor methodological quality, scoring $3 / 10$. Four studies (57\%) were classified as fair quality and two

241 studies (28\%) classified as good quality. None of the studies blinded subjects or therapists. All

242 studies had a between group comparison. 
244 The interrater agreeability between the two reviewers was $81 \%$ (6 of 7 items). The Kappa score

245 for the measure of agreement between the two reviewers on the individual validity was 0.86

246 indicating an almost perfect agreement ${ }^{16}$. The case series noted a limited number of

247 participants, lack of control group, and randomization of selected interventions as a limitation

248 of the study ${ }^{28}$. Similarly, the case report also cited the small number of participants along with

249 a relatively short period of intervention and no medium- or long-term efficacy of topical

250 hydrogen as limitations ${ }^{29}$.

251

252 Discussion

253 Main findings

254 The purpose of this scoping review was to systematically identify the scientific literature

255 reporting on rehabilitation interventions for athletes RTS after acute LAS, and to (1) provide the

256 type and efficacy of interventions utilised (2) summarize the studies completed to date, and (3)

257 identify any knowledge gaps to inform future research. This review demonstrated that while

258 there was supporting evidence for the use of early dynamic training to rehabilitate athletes

259 post-acute LAS, the evidence was of low-moderate quality ${ }^{30-34}$. These findings are consistent

260 with existing literature that recommends a combination of early weight bearing exercises such

261 as proprioception, resistance, plyometric and functional training $37-41$. 
263 An ankle sprain can result in reduced strength and postural control which can increase risk of

264 re-injury and delay RTS. Given the high level manoeuvres associated with sport, rehabilitation

265 interventions targeting strength, force production and functional endurance have shown to

266 have favourable outcomes 3034313233 . In the early stages of a rehabilitation program following

267 LAS, hydrotherapy was shown to provide advantages over standard land-based therapy for a

268 sooner RTS ${ }^{27}$. Following the acute stage, progressive controlled rehabilitation involving jump

269 stretch flex bands and postural sway showed positive outcomes following LAS and should be

270 considered for inclusion to RTS training protocols. Additionally, rehabilitation programs

271 involving plyometric exercises such as cone hops with 180 degree turn and diagonal cone

272 hops improved functional performance after LAS with the combined effect of strength and

273 speed enhancement ${ }^{30}{ }^{31}$. While passive treatments such as non-invasive interactive

274 neurostimulation may improve short-term outcomes such as pain, however long-term

275 outcomes show no significant difference on an athlete's ability to RTS ${ }^{35}$.

276 The results of one systematic review favoured of early mobilisation, early exercise and external

277 ankle support, which may allow a safer and quicker RTS ${ }^{21}$. Although this review provided

278 support for functional treatment, the population of interest was not athletes only. Moreover,

279 none of the included systematic reviews had a sole focus on athletes RTS, instead athletes were

280 combined with the general population in all analyses 9,21-23,42. Most sports require movement

281 patterns that involve a combination of forces in multiple directions, whilst maintaining the need

282 for optimal technique ${ }^{43}$. Given the increased multidirectional forces associated with sports

283 when compared with a typical walking pattern, the increased demands of an athletic

284 population when developing a rehabilitation program should be considered. However, the 
current body of evidence available is largely focused on non-athletic populations or recreational athletes which utilise RTS as a secondary outcome.

Limitations of this review include the lack of RCTs available on LAS with respect athletes and

RTS and the relatively poor methodological quality of those studies that were available.

Although the inclusion criteria for this scoping review was broad, articles not available in

English or full text were excluded. Due to the considerable heterogeneity of the interventions base rehabilitation protocols after LAS on evidence-based practice.

Clinical and Research Implications

297 Clinicians should utilize the best available evidence within clinical practice to maximize positive

298 outcomes. Through sport specific rehabilitation, athletes may report less weakness, and

299 achieve greater return to baseline biomechanics and motor patterns of sporting movements.

Clinicians should monitor the progression through a multidisciplinary approach involving the 
306 should be utilized to produce optimal outcomes for athletes wishing to RTS 9,22,39. As previously

307 noted, a limitation of this review were the lack of high quality RCTs investigating these

308 interventions in an athlete only, RTS population. A consideration for the direction of future

309 research would be for clinical trial design on this topic to be of high quality and consistent use

310 of relevant outcome measures, such as athlete re-injury utilized.

312 Conclusion

313 The results of this scoping review provide moderate quality evidence to support for an early

314 weightbearing and dynamic exercise rehabilitation approach, in contrast to passive or

315 restrictive interventions in rehabilitation protocols for athletes after LAS. Given the higher

316 physical requirements in certain sports like cutting, jumping and hopping, rehabilitation

317 should be specific to these demands.

320 Funding sources: none to declare.

321 Conflict of interests: none to declare. 


\section{References}

325 1. Kerkhoffs GM, Van Dijk CN. Acute lateral ankle ligament ruptures in the athlete: the role of surgery. Foot Ankle Clin. 2013;18(2):215-218.

327 2. Kerkhoffs GM, Struijs PA, Marti RK, Assendelft WJ, Blankevoort L, van Dijk CN. WITHDRAWN: Different functional treatment strategies for acute lateral ankle ligament injuries in adults. Cochrane Database Syst Rev. 2013(3):Cd002938.

330

3. Malliaropoulos N, Papacostas E, Papalada A, Maffulli N. Acute lateral ankle sprains in track and field athletes: an expanded classification. Foot Ankle Clin. 2006;11(3):497-507.

4. Hertel J, Corbett RO. An Updated Model of Chronic Ankle Instability. J AthI Train. 2019;54(6):572-588.

5. Shah S, Thomas AC, Noone JM, Blanchette CM, Wikstrom EA. Incidence and Cost of Ankle Sprains in United States Emergency Departments. Sports Health. 2016;8(6):547-552.

6. Dubin JC, Comeau D, McClelland RI, Dubin RA, Ferrel E. Lateral and syndesmotic ankle sprain injuries: a narrative literature review. J Chiropr Med. 2011;10(3):204-219.

7. Kemler E, van de Port I, Backx F, van Dijk CN. A Systematic Review on the Treatment of Acute Ankle Sprain. Sports Medicine. 2011;41(3):185-197.

8. Polzer H, Kanz KG, Prall WC, et al. Diagnosis and treatment of acute ankle injuries: development of an evidence-based algorithm. Orthop Rev (Pavia). 2012;4(1):e5.

342 9. Seah R, Mani-Babu S. Managing ankle sprains in primary care: what is best practice? A systematic review of the last 10 years of evidence. Br Med Bull. 2011;97:105-135.

344 10. Kerkhoffs GM, van den Bekerom M, Elders LAM, et al. Diagnosis, treatment and prevention of ankle sprains: an evidence-based clinical guideline. British Journal of Sports Medicine. 2012;46(12):854-860. 
347 11. Kyaw SL, Moore, I. S., \& Oo, M. L. . A systematic review on the effectiveness of different functional treatments for acute ankle sprains. Journal of sports medicine \& Doping studies

12. Vuurberg G, Hoorntje A, Wink LM, et al. Diagnosis, treatment and prevention of ankle sprains: update of an evidence-based clinical guideline. Br J Sports Med. 2018;52(15):956.

13. Arksey H, O'Malley L. Scoping studies: towards a methodological framework. International Journal of Social Research Methodology. 2005;8(1):19-32.

14. Tricco AC, Lillie E, Zarin W, et al. PRISMA Extension for Scoping Reviews (PRISMA-ScR): Checklist and Explanation. Ann Intern Med. 2018;169(7):467-473.

15. Peters M, Godfrey, C., McInerney, P., Soares, C. B., Khalil, H., \& Parker, D. . Reviewers Manual Methodology for JBI Scoping Reviews 2015. 2015;2:3-24.

16. McHugh ML. Interrater reliability: the kappa statistic. Biochemia medica. 2012;22(3):276-282.

17. Hariohm K, Prakash V, Saravankumar J. Quantity and quality of randomized controlled trials published by Indian physiotherapists. Perspect Clin Res. 2015;6(2):91-97.

18. Kennelly J. Reducing Racial/Ethnic Disparities in Reproductive and Perinatal Outcomes. In: Springer: New York, NY, USA; 2011.

19. Lyons K, Radburn C, Orr R, Pope R. A Profile of Injuries Sustained by Law Enforcement Officers: A Critical Review. Int J Environ Res Public Health. 2017;14(2).

20. Lynch SA, Renstrom PA. Treatment of acute lateral ankle ligament rupture in the athlete.

\section{Conservative versus surgical treatment. Sports Med. 1999;27(1):61-71.}

367 21. Kemler E, van de Port I, Backx F, van Dijk CN. A systematic review on the treatment of acute 368 ankle sprain: brace versus other functional treatment types. Sports Med. 2011;41(3):185-197. systematic review. Arch Orthop Trauma Surg. 2013;133(8):1129-1141. 
371 23. Hubbard TJ, Aronson SL, Denegar CR. Does Cryotherapy Hasten Return to Participation? A

372 Systematic Review. J Athl Train. 2004;39(1):88-94.

373 24. van der Wees PJ, Lenssen AF, Hendriks EJ, Stomp DJ, Dekker J, de Bie RA. Effectiveness of exercise therapy and manual mobilisation in ankle sprain and functional instability: a systematic review. Aust J Physiother. 2006;52(1):27-37.

25. Hausmann M, Ober J, Lepley AS. The Effectiveness of Deep Oscillation Therapy on Reducing Swelling and Pain in Athletes With Acute Lateral Ankle Sprains. J Sport Rehabil. 2019:1-4.

26. Hawkins SW, Hawkins JR. CLINICAL APPLICATIONS OF CRYOTHERAPY AMONG SPORTS PHYSICAL THERAPISTS. International Journal of Sports Physical Therapy. 2016;11(1):141-148.

27. Kim E, Kim T, Kang H, Lee J, Childers MK. Aquatic versus land-based exercises as early functional rehabilitation for elite athletes with acute lower extremity ligament injury: a pilot study. Pm $r$. 2010;2(8):703-712.

28. May JM, Nasypany A, Paolino J, Baker R, Seegmiller J. Patient Outcomes Utilizing the Mulligan Concept of Mobilization With Movement to Treat Intercollegiate Patients Diagnosed With Lateral Ankle Sprain: An a Priori Case Series. J Sport Rehabil. 2017;26(6):486-496.

29. Javorac D, Stajer V, Ostojic S. Case Report: Acute hydrotherapy with super-saturated hydrogenrich water for ankle sprain in a professional athlete. F1000Res. 2020;9:245.

30. Van Der Linde E, Oschman Z. Comparative ultrasound study of acute lateral ankle ligament injuries rehabilitated with conventional and jump stretch flex band programmes. African Journal for Physical, Health Education, Recreation \& Dance. 2011;17(4):591-602. rehabilitation on strength, postural sway, position sense and re-injury risk after acute ankle ligament sprain. Scand J Med Sci Sports. 1999;9(2):104-109. 
32. Ismail MM, Ibrahim MM, Youssef EF, El Shorbagy KM. Plyometric training versus resistive exercises after acute lateral ankle sprain. Foot Ankle Int. 2010;31(6):523-530.

33. Hupperets MD, Verhagen EA, van Mechelen W. Effect of unsupervised home based proprioceptive training on recurrences of ankle sprain: randomised controlled trial. Bmj. 2009;339:b2684.

34. Karlsson J, Eriksson BI, Swärd L. Early functional treatment for acute ligament injuries of the ankle joint. Scand J Med Sci Sports. 1996;6(6):341-345.

35. Razzano C, Izzo R, Savastano R, Colantuoni C, Carbone S. Noninvasive Interactive Neurostimulation Therapy for the Treatment of Low-Grade Lateral Ankle Sprain in the Professional Contact Sport Athlete Improves the Short-Term Recovery and Return to Sport: A Randomized Controlled Trial. J Foot Ankle Surg. 2019;58(3):441-446.

36. Nunes GS, Vargas VZ, Wageck B, Hauphental DP, da Luz CM, de Noronha M. Kinesio Taping does not decrease swelling in acute, lateral ankle sprain of athletes: a randomised trial. J Physiother. 2015;61(1):28-33.

37. Anderson SJ. Acute ankle sprains: keys to diagnosis and return to play. Phys Sportsmed. 2002;30(12):29-35.

38. Kennedy JG, Hodgkins CW, Sculco P, Carter T, Robinson SP. Sports injuries of the foot and ankle in the adolescent athlete. International SportMed Journal. 2006;7(2):85-97.

39. McKeon PO, Donovan L. A Perceptual Framework for Conservative Treatment and Rehabilitation of Ankle Sprains: An Evidence-Based Paradigm Shift. J Athl Train. 2019;54(6):628-638. Arthrosc Rev. 2009;17(3):203-207. 
416 41. van den Bekerom MP, Kerkhoffs GM, McCollum GA, Calder JD, van Dijk CN. Management of acute lateral ankle ligament injury in the athlete. Knee Surg Sports Traumatol Arthrosc. 2013;21(6):1390-1395.

419 42. van der Wees PJ, Lenssen AF, Hendriks EJM, Stomp DJ, Dekker J, de Bie RA. Effectiveness of exercise therapy and manual mobilisation in acute ankle sprain and functional instability: a

421 systematic review. Australian Journal of Physiotherapy. 2006;52(1):27-37.

422 43. Kolt GS. Research on the ankle in sport. J Sci Med Sport. 2013;16(5):387.

423

424

425

426

427

428

429

430

431

432

433

434 


\section{Tables}

\section{Table 1. Summary of included systematic reviews}

\begin{tabular}{|c|c|c|c|c|c|c|}
\hline $\begin{array}{l}\text { Author } \\
\text { (year) }\end{array}$ & Title & Aim & Dates & $\begin{array}{c}\text { Methodological } \\
\text { quality }\end{array}$ & $\begin{array}{l}\text { Number } \\
\text { of studies }\end{array}$ & Key findings \\
\hline $\begin{array}{l}\text { Kemler } \\
\text { et } \\
\text { al.2011 }\end{array}$ & $\begin{array}{l}\text { A Systematic Review on } \\
\text { the Treatment of Acute } \\
\text { Ankle Sprain Brace versus } \\
\text { Other Functional } \\
\text { Treatment Types }\end{array}$ & $\begin{array}{l}\text { To evaluate the effectiveness of } \\
\text { braces as a treatment compared } \\
\text { with functional treatments such } \\
\text { as ankle tape and elastic } \\
\text { bandages }\end{array}$ & $\begin{array}{l}1990- \\
2009\end{array}$ & Not assessed & 8 & $\begin{array}{l}\text { A few individual studies } \\
\text { reported positive functional } \\
\text { outcomes after treatment } \\
\text { with an ankle brace } \\
\text { compared with other } \\
\text { functional methods }\end{array}$ \\
\hline $\begin{array}{l}\text { Hubbard } \\
\text { et al. } \\
2004\end{array}$ & $\begin{array}{l}\text { Does Cryotherapy Hasten } \\
\text { Return to Participation? A } \\
\text { systematic review }\end{array}$ & $\begin{array}{l}\text { To search original research } \\
\text { addressing the effect of } \\
\text { cryotherapy on return to } \\
\text { participation after injury }\end{array}$ & $\begin{array}{l}1967- \\
2003\end{array}$ & $\begin{array}{l}\text { Poor quality } \\
\text { evidence }\end{array}$ & 4 & $\begin{array}{l}\text { Cryotherapy may have a } \\
\text { positive effect on return-to- } \\
\text { participation measures with } \\
\text { the relatively poor quality of } \\
\text { the studies reviewed }\end{array}$ \\
\hline $\begin{array}{l}\text { Van Der } \\
\text { Wees et } \\
\text { al. } 2006\end{array}$ & $\begin{array}{l}\text { Effectiveness of exercise } \\
\text { therapy and manual } \\
\text { mobilisation in acute ankle } \\
\text { sprain and functional } \\
\text { instability: A systematic } \\
\text { review }\end{array}$ & $\begin{array}{l}\text { Critically review the } \\
\text { effectiveness of exercise therapy } \\
\text { and manual mobilisation in } \\
\text { acute ankle sprains and } \\
\text { functional instability by } \\
\text { conducting a systematic review } \\
\text { of RCTs }\end{array}$ & $\begin{array}{l}1966- \\
2005\end{array}$ & $\begin{array}{l}\text { Poor quality } \\
\text { evidence }\end{array}$ & 17 & $\begin{array}{l}\text { Manual mobilisation has an } \\
\text { initial positive effect on } \\
\text { dorsiflexion ROM }\end{array}$ \\
\hline $\begin{array}{l}\text { Petersen } \\
\text { et al. } \\
2013\end{array}$ & $\begin{array}{l}\text { Treatment of acute ankle } \\
\text { ligament injuries: A } \\
\text { systematic review }\end{array}$ & $\begin{array}{l}\text { To perform a systematic } \\
\text { literature review of the last } 10 \\
\text { years regarding evidence for the } \\
\text { treatment and prevention of LAS }\end{array}$ & $\begin{array}{l}2002- \\
2012\end{array}$ & $\begin{array}{l}\text { Poor quality } \\
\text { evidence }\end{array}$ & 20 & $\begin{array}{l}\text { Majority of LAS can be } \\
\text { managed without surgery. } \\
\text { The results support a phase } \\
\text { adapted non-surgical } \\
\text { treatment of acute LAS with } \\
\text { a short-term immobilization } \\
\text { for grade III injuries followed } \\
\text { by a semi-rigid brace }\end{array}$ \\
\hline
\end{tabular}




\begin{tabular}{|c|c|c|c|c|c|c|}
\hline $\begin{array}{l}\text { Seah et } \\
\text { al. } 2011\end{array}$ & $\begin{array}{l}\text { Managing ankle sprains in } \\
\text { primary care: what is best } \\
\text { practice? A systematic } \\
\text { review of the last } 10 \text { years } \\
\text { of evidence }\end{array}$ & $\begin{array}{l}\text { To summarize the best available } \\
\text { evidence in the last decade for } \\
\text { managing ankle sprains in the } \\
\text { community }\end{array}$ & $\begin{array}{l}2000- \\
2009\end{array}$ & Limited & 33 & $\begin{array}{l}\text { Management is not readily } \\
\text { agreed. In mild-to-moderate } \\
\text { sprains, functional treatment } \\
\text { was better than } \\
\text { immobilization. In severe } \\
\text { sprains, short period of } \\
\text { immobilization in a } \\
\text { cast/brace results in a } \\
\text { quicker recovery than } \\
\text { compression bandage alone. } \\
\text { Supervised rehabilitation } \\
\text { with conventional treatment } \\
\text { can be beneficial }\end{array}$ \\
\hline
\end{tabular}

Methodological quality was determined by the individual reviewers not the authors of this study. The conclusion stated is that of the included review in reference to interventions for rehabilitation following LAS. The number of original studies is only those included in each review.

\section{Table 2. RCT Study Characteristics}

\begin{tabular}{|c|c|c|c|c|c|c|c|}
\hline \multirow{2}{*}{$\begin{array}{l}\text { Author } \\
\text { (year) }\end{array}$} & \multirow{2}{*}{ Title } & \multirow{2}{*}{ Population } & \multirow{2}{*}{ Sport } & \multirow{2}{*}{$\begin{array}{l}\text { Number of } \\
\text { participants }\end{array}$} & \multirow{2}{*}{$\begin{array}{l}\text { Age } \\
\text { (Mean) }\end{array}$} & \multicolumn{2}{|c|}{ Sex } \\
\hline & & & & & & Male & Female \\
\hline $\begin{array}{l}\text { Razzano } \\
\text { et al. } \\
\text { (2018) }\end{array}$ & $\begin{array}{l}\text { Non-invasive Interactive } \\
\text { Neurostimulation Therapy for the } \\
\text { Treatment of Low-Grade Lateral Ankle } \\
\text { Sprain in the Professional Contact Sport } \\
\text { Athlete Improves the Short-Term } \\
\text { Recovery and Return to Sport }\end{array}$ & $\begin{array}{l}\text { Professional athletes with a } \\
\text { diagnosis of grade I or II LAS that } \\
\text { occurred during a contact sport } \\
\text { competition }\end{array}$ & $\begin{array}{l}\text { Soccer, football, } \\
\text { basketball, mixed } \\
\text { martial arts }\end{array}$ & 61 & 23 & 27 & 10 \\
\hline $\begin{array}{l}\text { Kim et } \\
\text { al. } \\
(2010)\end{array}$ & $\begin{array}{l}\text { Aquatic Versus Land-based Exercises as } \\
\text { Early Functional Rehabilitation for Elite } \\
\text { Athletes with Acute Lower Extremity } \\
\text { Ligament Injury }\end{array}$ & $\begin{array}{l}\text { Professional athletes with } \\
\text { isolated grade I or II ligament } \\
\text { injury in ankle }\end{array}$ & Unspecified & 22 & 26 & 0 & 22 \\
\hline
\end{tabular}




\begin{tabular}{|c|c|c|c|c|c|c|c|}
\hline $\begin{array}{l}\text { Karlsson } \\
\text { et al. } \\
\text { (1996) }\end{array}$ & $\begin{array}{l}\text { Early functional treatment for acute } \\
\text { ligament injuries of the ankle joint }\end{array}$ & $\begin{array}{l}\text { Recreational or competitive } \\
\text { athletes with acute }(<24 \mathrm{~h}) \text { grade } \\
\text { I or II lateral ligament ruptures }\end{array}$ & Unspecified & 86 & 22 & 57 & 29 \\
\hline $\begin{array}{l}\text { Van Der } \\
\text { Linde et } \\
\text { al. } \\
(2011)\end{array}$ & $\begin{array}{l}\text { Comparative ultrasound study of acute } \\
\text { lateral ankle ligament injuries } \\
\text { rehabilitated with conventional, and } \\
\text { jump stretch flex band programs }\end{array}$ & $\begin{array}{l}\text { Active athletes who sustained } \\
\text { grade I or grade II ankle } \\
\text { ligamentous injuries }\end{array}$ & Unspecified & 25 & 21.6 & 19 & 6 \\
\hline $\begin{array}{l}\text { Holme et } \\
\text { al. } \\
\text { (1999) }\end{array}$ & $\begin{array}{l}\text { The effect of supervised rehabilitation on } \\
\text { strength, postural sway, position sense } \\
\text { and re-injury risk after acute ankle } \\
\text { ligament sprain }\end{array}$ & Recreational athletes & Unspecified & 92 & 26 & 44 & 27 \\
\hline $\begin{array}{l}\text { Ismail et } \\
\text { al. } \\
(2010)\end{array}$ & $\begin{array}{l}\text { Plyometric Training Versus Resistive } \\
\text { Exercises After Acute Lateral Ankle } \\
\text { Sprain }\end{array}$ & Athletes with grade I or II LAS & $\begin{array}{l}\text { Basketball, } \\
\text { handball, football, } \\
\text { running }\end{array}$ & 22 & 27 & 11 & 11 \\
\hline $\begin{array}{l}\text { Hupperts } \\
\text { et al. } \\
\text { (2007) }\end{array}$ & $\begin{array}{l}\text { Effect of unsupervised home-based } \\
\text { proprioceptive training on recurrences of } \\
\text { ankle sprain }\end{array}$ & $\begin{array}{l}\text { Recreational athletes with a LAS } \\
<2 \text { months }\end{array}$ & Unspecified & 522 & 48 & 136 & 120 \\
\hline
\end{tabular}

Table 3. Study aims and key findings

\begin{tabular}{lll}
\hline $\begin{array}{l}\text { Author } \\
\text { (year) }\end{array}$ & Aim & Key Findings/Conclusion \\
\hline $\begin{array}{l}\text { Razzano et } \\
\text { al. (2018) }\end{array}$ & $\begin{array}{l}\text { To compare the results of improvement of a foot functional } \\
\text { score, lower level of reported pain, and return to sports in } 2 \\
\text { groups of contact sport athletes affected by a grade I or II LAS }\end{array}$ & $\begin{array}{l}\text { Non-invasive interactive neurostimulation can improve } \\
\text { short-term outcomes that can hasten RTS in athletes with } \\
\text { acute grade I or II ankle sprain }\end{array}$ \\
\hline $\begin{array}{lll}\text { Kim et al. } \\
\mathbf{( 2 0 1 0 )}\end{array}$ & $\begin{array}{l}\text { To compare outcomes between aquatic and land-based } \\
\text { exercises during early-phase recovery from acute lower } \\
\text { extremity ligament injuries in elite athletes }\end{array}$ & $\begin{array}{l}\text { Aquatic therapy showed more rapid improvement in pain } \\
\text { compared with land-based interventions }\end{array}$ \\
& &
\end{tabular}




\begin{tabular}{|c|c|c|c|}
\hline $\begin{array}{l}\text { Karlsson } \\
\text { et al. } \\
(1996)\end{array}$ & $\begin{array}{l}\text { To compare two different non-surgical treatment modalities } \\
\text { in patients with grade I and II LAS }\end{array}$ & Early dynamic training resulted in an earlier RTS & 4 \\
\hline $\begin{array}{l}\text { Van Der } \\
\text { Linde et al. } \\
\text { (2011) }\end{array}$ & $\begin{array}{l}\text { To establish the difference in rehabilitation outcomes } \\
\text { between the Jump Stretch Flex Band (JSFB) programme and } \\
\text { conventional ankle rehabilitation programmes of acute LAS }\end{array}$ & $\begin{array}{l}\text { The JSFB group showed a decrease in anterior/posterior } \\
\text { recess fluid, increase in ligament size and shortened time to } \\
\text { RTS }\end{array}$ & 5 \\
\hline $\begin{array}{l}\text { Holme et } \\
\text { al. (1999) }\end{array}$ & $\begin{array}{l}\text { The effect of an early rehabilitation program, including } \\
\text { postural training, on ankle joint function after LAS }\end{array}$ & $\begin{array}{l}\text { Supervised early dynamic training showed an increase in } \\
\text { isometric ankle strength and postural control }\end{array}$ & 3 \\
\hline $\begin{array}{l}\text { Ismail et } \\
\text { al. (2010) }\end{array}$ & $\begin{array}{l}\text { To determine the effects of plyometric training versus } \\
\text { resistive exercises on muscle strength and function following } \\
\text { acute LAS }\end{array}$ & $\begin{array}{l}\text { Plyometric training improved functional performance after } \\
\text { LAS with the combined effect of strength and speed } \\
\text { enhancement }\end{array}$ & 6 \\
\hline $\begin{array}{l}\text { Hupperets } \\
\text { et al. } \\
(2007)\end{array}$ & $\begin{array}{l}\text { To evaluate the effectiveness of an unsupervised } \\
\text { proprioceptive training programme on recurrences of ankle } \\
\text { sprain after usual care in athletes who had sustained an acute } \\
\text { sports related LAS }\end{array}$ & $\begin{array}{l}\text { Proprioceptive training program is effective for the } \\
\text { prevention of self-reported recurrences }\end{array}$ & 8 \\
\hline
\end{tabular}

\section{Table 4. Intervention and outcome details}

\begin{tabular}{|c|c|c|c|c|}
\hline $\begin{array}{l}\text { Author } \\
\text { (year) }\end{array}$ & Intervention details & Outcome & Measurement tool: Unit & $\begin{array}{l}\text { Follow } \\
\text { up }\end{array}$ \\
\hline $\begin{array}{l}\text { Razzano } \\
\text { et al. } \\
(2018)\end{array}$ & $\begin{array}{l}\text { Electro-modalities: Non-invasive } \\
\text { interactive neurostimulation vs } \\
\text { sham device }\end{array}$ & $\begin{array}{l}\text { 1. Pain } \\
\text { 2. Self-Reported Functional Impairment } \\
\text { Walking Ability }\end{array}$ & $\begin{array}{l}\text { 1. VAS: } 0-10 . \\
\text { 2. Inability Walking Scale (IWS): 0-10 }\end{array}$ & $\begin{array}{c}2 \& 4 \\
\text { months }\end{array}$ \\
\hline $\begin{array}{l}\text { Kim et al. } \\
(2010)\end{array}$ & $\begin{array}{l}\text { Aquatic therapy: Aquatic } \\
\text { Therapy vs Land Based exercise }\end{array}$ & $\begin{array}{l}\text { 1. Pain } \\
\text { 2. Static/Dynamic Stability (Biodex } \\
\text { Balance System) } \\
\text { 3. Percentage single-limb support time }\end{array}$ & $\begin{array}{l}\text { 1. VAS: } 100 \mathrm{~mm} \text { line. } \\
\text { 2. Biodex Medical System, Electric scale } \\
\text { level 1-3. } \\
\text { 3. Instrumented walkway system, GAITRite: }\end{array}$ & $\mathrm{N} / \mathrm{A}$ \\
\hline
\end{tabular}




(GAITrite) seconds

\begin{tabular}{|c|c|c|c|c|}
\hline $\begin{array}{l}\text { Karlsson } \\
\text { et al. } \\
\text { (1996) }\end{array}$ & $\begin{array}{l}\text { Early dynamic training: } \\
\text { Compression pads, early weight } \\
\text { bearing, ROM training vs } \\
\text { compression wrapping, partial } \\
\text { weight bearing (PWB) and } \\
\text { crutches }\end{array}$ & $\begin{array}{l}\text { 1. Stability } \\
\text { 2. Pain } \\
\text { 3. Swelling } \\
\text { 4. Stiffness } \\
\text { 5. Work/sport/activities of daily living } \\
\text { 6. Running } \\
\text { 7. Stair climbing } \\
\text { 8. Support }\end{array}$ & $\begin{array}{l}\text { 1-8. Orthopaedic surgeon scoring scale: } 0 \text { - } \\
100\end{array}$ & $\begin{array}{c}18 \\
\text { months }\end{array}$ \\
\hline $\begin{array}{l}\text { Van Der } \\
\text { Linde et } \\
\text { al. (2011) }\end{array}$ & $\begin{array}{l}\text { Early dynamic training : } \\
\text { Jump stretch flex band program } \\
\text { (JSFB) with ultrasound vs } \\
\text { conventional ankle } \\
\text { rehabilitation with ultrasound }\end{array}$ & $\begin{array}{l}\text { 1. Change in ligament size } \\
\text { 2. Decrease of fluid in anterior/posterior } \\
\text { recess } \\
\text { 3. Time until RTS }\end{array}$ & $\begin{array}{l}\text { 1-2. Ultrasound machine }(7.5-14 \mathrm{MHz} \\
\text { linear probe): To the closest } 0.01 \mathrm{~mm} \text {. } \\
\text { 3. Calendar: days }\end{array}$ & N/A \\
\hline $\begin{array}{l}\text { Holme et } \\
\text { al. (1999) }\end{array}$ & $\begin{array}{l}\text { Early dynamic training: Early } \\
\text { ankle mobilization, strength, } \\
\text { mobility vs supervised } \\
\text { physiotherapy }\end{array}$ & $\begin{array}{l}\text { 1. Position sense } \\
\text { 2. Isometric strength } \\
\text { 3. Postural sway }\end{array}$ & $\begin{array}{l}\text { 1. Torsiometer: Degrees } \\
\text { 2. Dynamometer: } \mathrm{Nm} \\
\text { 3. Force Platform: } \mathrm{Cm}\end{array}$ & $\begin{array}{c}12 \\
\text { months }\end{array}$ \\
\hline $\begin{array}{l}\text { Ismail et } \\
\text { al. (2010) }\end{array}$ & $\begin{array}{l}\text { Early dynamic training: } \\
\text { Plyometric training vs Resistive } \\
\text { exercises }\end{array}$ & $\begin{array}{l}\text { 1. Climbing down-stairs } \\
\text { 2. Raising on heel } \\
\text { 3. Raising on toes } \\
\text { 4. Single limb stance } \\
\text { 5. Eversion/inversion strength }\end{array}$ & $\begin{array}{l}\text { 1. Stopwatch: seconds } \\
\text { 2-3. Number repetitions: Numerical } \\
\text { 4. Stopwatch: Seconds } \\
\text { 5. Dynamometer: } \mathrm{Nm} / \mathrm{kg}\end{array}$ & N/A \\
\hline $\begin{array}{l}\text { Hupperets } \\
\text { et al. } \\
\text { (2007) }\end{array}$ & $\begin{array}{l}\text { Early dynamic training: Usual } \\
\text { care (any form of rehabilitation } \\
\text { used by an athlete) vs usual care } \\
\text { and proprioceptive training }\end{array}$ & 1. Self- reported Ankle Sprain & 1. Number of Incidences: Numerical & $\begin{array}{c}12 \\
\text { months }\end{array}$ \\
\hline
\end{tabular}


Manuscript has been published online as Ahead of Print:

Accepted author manuscript version reprinted, by permission, from Journal of Sport Rehabilitation (2021). https://doi.org/10.1123/jsr.2021-0244

$$
\text { (c) } 2021 \text { Human Kinetics, Inc. }
$$




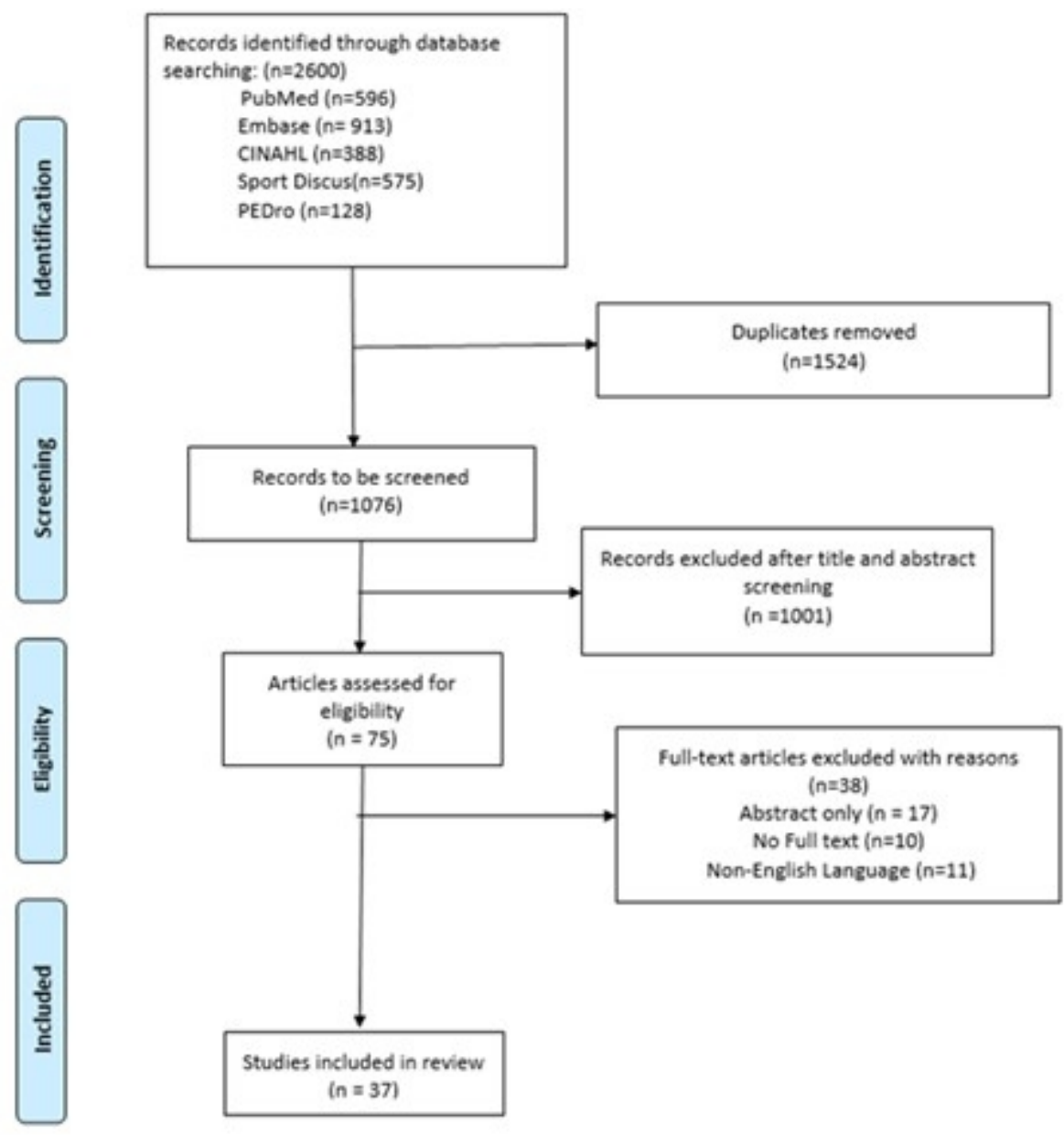

$121 \times 127 \mathrm{~mm}(96 \times 96 \mathrm{DPI})$

Manuscript has been published online as Ahead of Print: (C) 2021 Human Kinetics, Inc. 


\section{Supplementary Material}

\begin{tabular}{|c|c|c|c|c|c|c|c|c|c|c|c|c|}
\hline $\begin{array}{l}\text { Author } \\
\text { (year) }\end{array}$ & 昙 & $\begin{array}{l}\text { D } \\
\frac{\mathscr{n}}{E} \\
\frac{0}{0} \\
\frac{0}{0} \\
\frac{1}{\mathbb{D}} \\
\simeq\end{array}$ & 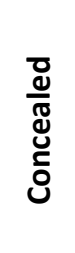 & 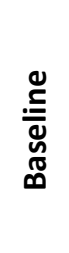 &  &  & 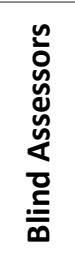 & 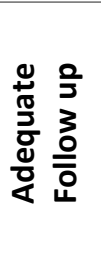 & 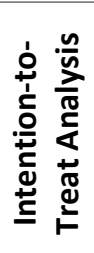 & 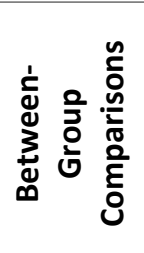 & 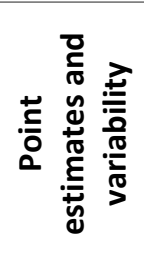 & Score \\
\hline $\begin{array}{l}\text { Razzano et al. } \\
2018\end{array}$ & Yes & Yes & No & Yes & No & No & Yes & Yes & No & Yes & Yes & 6 \\
\hline $\begin{array}{l}\text { Hupperts et al. } \\
2007\end{array}$ & Yes & Yes & Yes & Yes & No & No & Yes & Yes & Yes & Yes & Yes & 8 \\
\hline $\begin{array}{l}\text { Eriksson et al. } \\
1996\end{array}$ & No & Yes & No & No & No & No & No & No & Yes & Yes & Yes & 4 \\
\hline $\begin{array}{l}\text { Van Der Linde } \\
\text { et al. } \\
2011\end{array}$ & Yes & Yes & No & No & No & No & No & Yes & Yes & Yes & Yes & 5 \\
\hline $\begin{array}{l}\text { Ismail et al. } \\
2010\end{array}$ & Yes & Yes & Yes & Yes & No & No & Yes & No & No & Yes & Yes & 6 \\
\hline $\begin{array}{l}\text { Holme et al. } \\
1999\end{array}$ & Yes & Yes & No & No & No & No & No & No & No & Yes & Yes & 3 \\
\hline Kim et al. 2010 & Yes & Yes & No & Yes & No & No & Yes & Yes & No & Yes & Yes & 6 \\
\hline
\end{tabular}


Supplementary Figure 1. Number of included studies by study design type

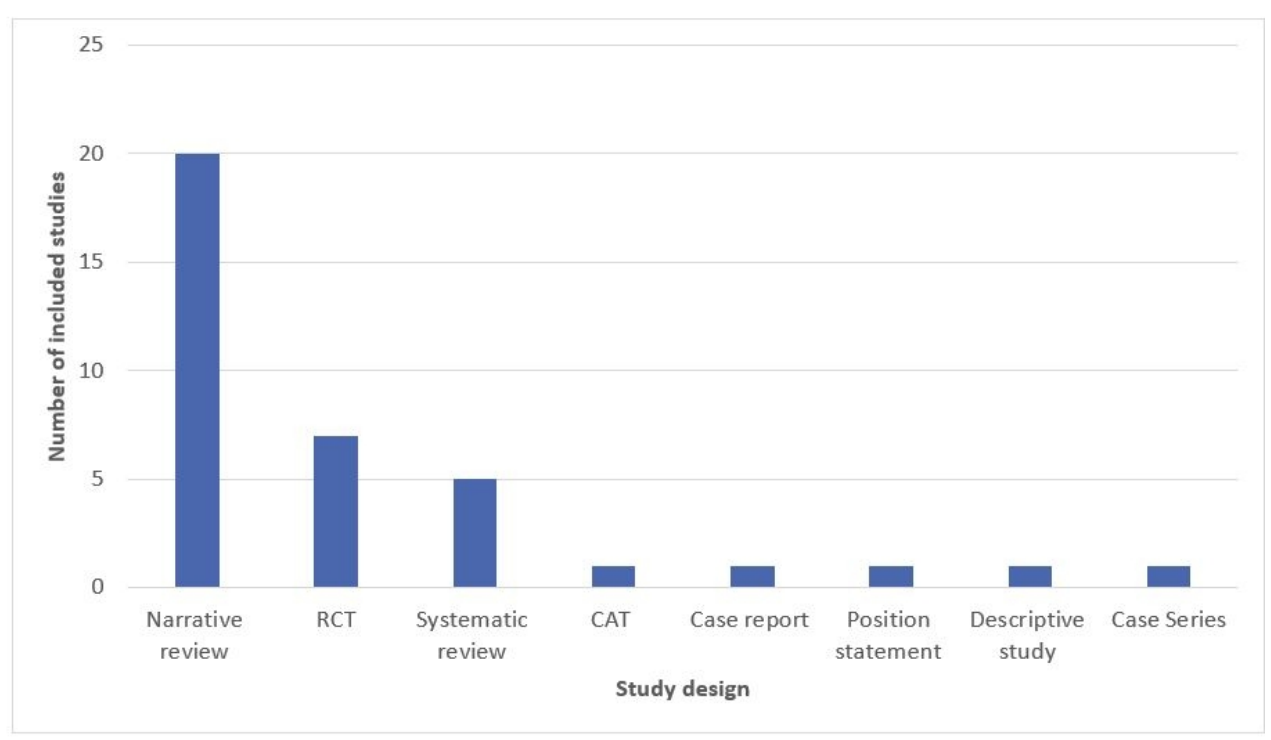

$199 \times 132 \mathrm{~mm}(120 \times 120 \mathrm{DPI})$

Manuscript has been published online as Ahead of Print: (C) 2021 Human Kinetics, Inc. 